\title{
Soft-Tissue Tumor Reporting and Data System (St-Rads): Mri Reporting Guideline with Multi-Institutional Validation Study of Extremity Soft Tissue Tumors
}

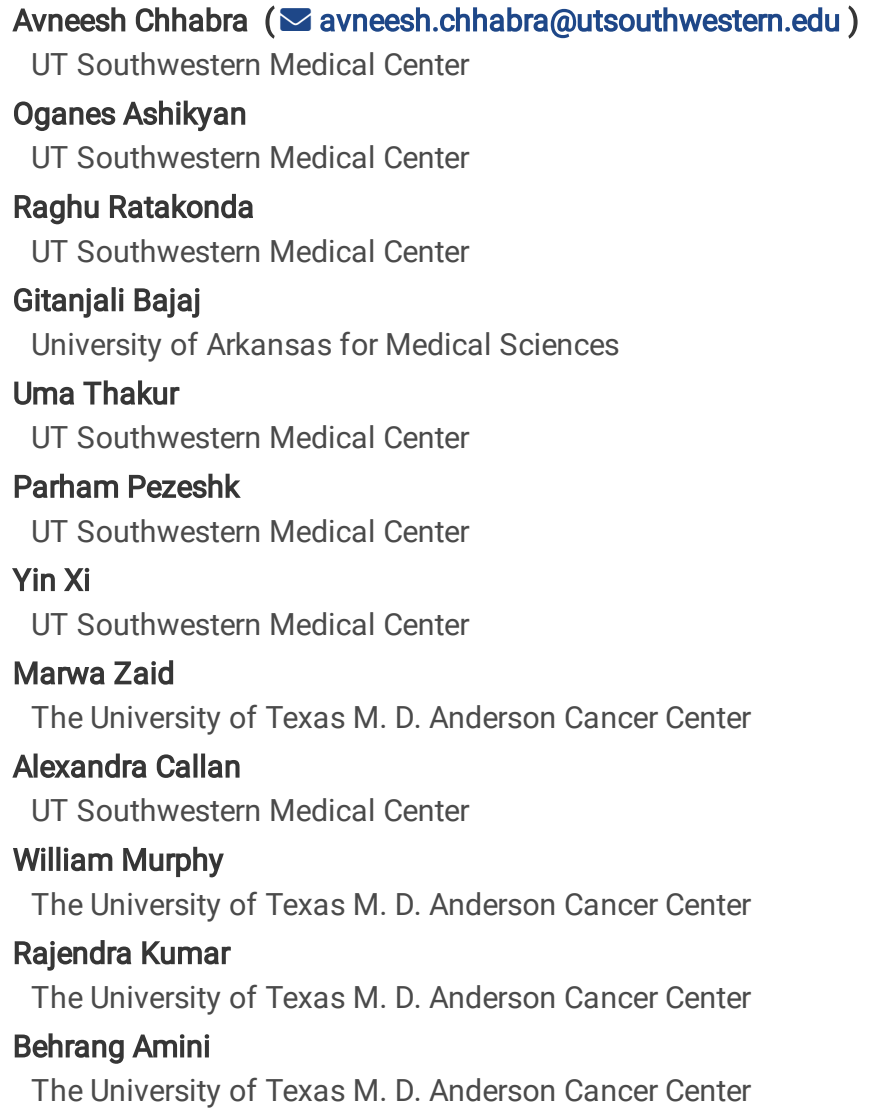

\section{Research Article}

Keywords: Sarcoma, MRI, Extremities, Biopsy, Guideline

Posted Date: February 9th, 2022

DOl: https://doi.org/10.21203/rs.3.rs-1269197/v1

License: (c) (i) This work is licensed under a Creative Commons Attribution 4.0 International License. Read Full License 


\section{Abstract}

\section{Background}

To our knowledge, no current guideline exists in outlining follow-up or interventional strategies in musculoskeletal soft tissue tumor management. To develop and validate soft-tissue tumor reporting and data system (ST-RADS) with the hypothesis that the proposed guideline reliably and accurately assists in separating benign from malignant musculoskeletal soft tissue tumors.

\section{Methods}

This is a multi-institutional cross-sectional study of soft-tissue masses. An expert consensus agreement was reached for ST-RADS categories using the terminology from WHO classification. Adipocytic tumors, T2-hyperintense and T2-hypointense masses of extremities with a wide spectrum of histologies were assessed. MRI categories were: STRADS 0 - incomplete imaging, I - no lesion identified, II - definitely benign, III probably benign, IV - indeterminate or suspicious for malignancy, V- highly suggestive of malignancy, and VI - known biopsy-proven malignancy or recurrence. Eight readers evaluated cases and ICC and AUC were calculated.

\section{Results}

200 soft tissue masses were tested. There was good inter-reader agreement with ICC $0.72[95 \% \mathrm{Cl}=0.64-0.79]$ and $0.69[95 \% \mathrm{Cl}=0.59-0.70]$ for adipocytic and T2-hyperintense, and fair, 0.48 [95\% $\mathrm{Cl}=0.35-0.62]$ for T2-hypointense masses. The sensitivity and specificity for detection of malignancy were $96 \%$ and $63 \%, 93 \%$ and $71 \%, 64 \%$ and $84 \%$ for adipocytic, T2-hyperintense, and T2-hypointense masses, respectively. The AUC was 0.79-0.89.

\section{Conclusion}

ST-RADS guideline using standardized terminology stratifies musculoskeletal tumors into benign and malignant categories and provides management strategy. This MRI-based guideline is meant to be a "dynamic" document that can be further refined and updated in response to future user feedback and as new scientific data becomes available.

\section{Key Points}

- ST-RADS shows good inter-reader agreements (ICC= 0.72 and 0.69) for adipocytic and T2-hyperintense musculoskeletal soft tissue masses and fair (ICC=0.48) for T2-hypointense masses.

- ST-RADS allows good to excellent AUC for different soft tissue tumors (0.79-0.89).

- - ST-RADS guideline is a valid system for attending readers with different experience levels.

\section{Introduction}

Soft tissue tumors of extremities are commonly encountered [22,33]. These musculoskeletal tumors vary from ganglion cysts and lipomas to malignant sarcomas with confounding clinical presentations. These occur across all demographics, with benign soft tissue tumors being one hundred times more common than malignant tumors [47]. Malignant soft tissue tumors, though uncommon, lead to a substantial impact on the health system. While the total economic costs of soft tissue sarcomas are unknown, the financial burden can easily reach $\$ 100,000$ per patient [1].

While ultrasound is a good screening tool, magnetic resonance imaging (MRI) is the non-invasive modality of choice to evaluate soft tissue tumors due to its inherent superior soft-tissue contrast $[12,27,55,56]$. MRI is useful for tumor localization, tissue characterization, and local staging to guide biopsy and surgical planning $[13,18,51]$. Despite advances in imaging, rendering a specific diagnosis for these soft tissue tumors and tumor-like lesions (tumor mimics) remains challenging. The tumors can be predominantly hyperintense or hypointense on T2weighted (T2W) imaging with nonspecific imaging findings and require a biopsy for confirmation [51, 57]. For malignant soft tissue tumors, the final diagnosis is usually established after histopathological analysis, and staging on imaging along with multidisciplinary discussion with teams of experts ultimately dictates the management [18]. Traditional treatment for benign masses can vary from conservative management or surgical excision while a combination of radiation, chemotherapy, and surgical excision is used for higher-grade malignant tumors. Biopsy and surgery can provide definitive diagnosis but are invasive measures and may unnecessarily pose unwanted risks to the patients [16, 20]. In patients at low risk of malignancy on imaging, such as typical ganglion cyst, vascular malformations, etc., the aim is to maximize outcomes and minimize morbidity and psychological stress by eliminating unnecessary biopsy and surgical procedures. However, these goals may not be achieved without a clinically meaningful classification system or standardized guidelines. 
To the authors' knowledge, there are no validated or standardized guidelines for a MRI reading radiologist that aid in the differentiation of benign from malignant soft tissue tumors, outline strategy for follow-up, or dictate the necessity for invasive measures, such as biopsy and surgery. To that end, experienced musculoskeletal radiologists from three tertiary care university centers created a MRI reporting guideline for extremity softtissue tumors (Soft-tissue Tumor Reporting And Data System, ST-RADS) like the BI-RADS (Breast Imaging- Reporting and Data System) classification used for breast tumors [5, 38], and the tumors were placed in different classes based on the recent World Health Organization (WHO) classification published in 2020 [54]. Since soft tissue tumors encompass a variety of histologies, validation of this classification system was performed using a multi-reader blinded evaluation of a large spectrum of soft tissue tumors and tumor-like lesions.

This study aims to develop and validate a standardized guideline that radiologists can use to differentiate benign from malignant soft tissue tumors and suggest appropriate management. We hypothesized that ST-RADS shows multi-reader reliability and can differentiate benign from malignant tumors with good accuracy (AUC).

\section{Materials And Methods}

This was a retrospective, HIPAA compliant, cross-sectional multi-institutional and multi-reader study involving three institutions. Anonymized MRI studies (with all 18 HIPAA identifiers stripped) were presented to the readers with proven cases randomly extracted from different institutions as part of retrospective Institutional review boards e.g. the experimental protocol was approved by UT Southwestern institutional IRB (STU 112017-003). As per this IRB, the informed consent was waived by UTSW ethics committee. No data use agreement is required for such studies without HIPAA information.

Inclusion criteria: Musculoskeletal soft tissue tumors of upper and lower extremities with complete MR imaging sets (as defined below) of adipocytic (fat containing on MRI or histology), T2-hyperintense tumors and tumor-like lesions (hyperintense than muscle signal) and T2hypointense masses and tumor-like lesions with histology proof via biopsy and/or final post-surgical histology, and the exclusion criteria were incomplete imaging set and lack of final clinical diagnosis, e.g. lack of arthroscopy for parameniscal cyst or final clinical diagnosis of Gout.

\section{Development of Soft-tissue Tumor Reporting And Data System (ST-RADS) consensus document}

ST-RADS consensus document was created by reviewing WHO document, the consensus opinion of tumor imaging experts from all three institutes, input from clinicians and expert methodologist from the primary institution (Table. 1). WHO classification of soft tissue tumors was used as a guide to place a spectrum of commonly encountered histologies in various categories of ST-RADS (Table. 2). As indicated in Table. 1, all soft tissue tumors were classified into one of the ST-RADS categories 0-VI as outlined in Table.3 and were evaluated for study purposes.

ST-RADS O was used in the event of a non-diagnostic study / incomplete imaging, and further imaging is required.

A complete MR imaging study is defined as the one with full tumor coverage in each of these imaging sequences in at least one plane: T1W imaging (T1WI), fluid sensitive sequence (fat suppressed T2WI or T2WI, or inversion recovery), and post-contrast fsT1WI. An incomplete MR imaging study is defined as the absence of one of the above-described sequences $[55,58,59]$.

A recent examination with an additional complement of MRI sequences may suffice as complete MR imaging if obtained within two weeks of an incomplete imaging set. Diffusion-weighted imaging (DWI) is an emerging modality and is not universally used [9, 23, 46]. Apparent diffusion coefficient (ADC), if available during interpretation, can be used as a supplemental finding for the diagnosis $[3,9,23,42,46,49]$.

ST-RADS / was used if no lesion is identified, and no further follow-up is needed.

ST-RADS // was used when the lesion is definitely benign, and no follow-up needed. Representative masses include simple lipoma with a uniform fat signal on all sequences with complete suppression on fat saturation or inversion recovery images and no appreciable enhancement, can be upto $10 \mathrm{~cm}[8,17,19]$, completely calcified hypointense lesions as also confirmed with radiographs or CT imaging, or fluid intensity (markedly hypointense on T1WI and markedly hyperintense on T2W) mass connected to a joint or bursa with no intravenous contrast enhancement [32, 37]. Other masses include those with classic imaging features and spatial location of a benign tumor, such as plantar fibroma, fat necrosis [48], elastofibroma dorsi of chest wall [44, 49], fibrolipoma of nerve [30, 31, 53], hemangioma or venous malformation with phlebolith (s), especially with additional radiographic demonstration $[12,60]$, peri-articular gouty tophus with cortical erosions (especially if radiographs are available) in the setting of elevated serum uric acid levels, Morel-Lavallée lesion [52], parameniscal or paralabral cyst or geyser phenomenon, venous or lymphatic malformation [16], sarcoid or rheumatoid nodule in classic locations with a known history of the respective systemic disease, Morton's neuroma, and thrombosed vein or artery. ST-RADS II lesions usually show no enhancement or thin ( $<2 \mathrm{~mm})$ peripheral and/or septal enhancement on the post-contrast study with no significant diffusion restriction. Variable enhancement may be seen with otherwise classic

Page $3 / 21$ 
lesions, such as plantar fibroma, Morton's neuroma, elastofibroma dorsi, hemangioma and arthritis related nodules. DWI, if obtained, exhibits moderate-marked hyperintensity of the lesion on both DWI and ADC images, with a mean ADC value $>1.5-3.0 \times 10^{-3} \mathrm{~mm}^{2} / \mathrm{s}[9]$.

ST-RADS II/ was used for probably benign masses with less than or equal to a $2 \%$ chance of malignancy. These masses are recommended to be followed until two years or until the lesion spontaneously resolves or significantly regresses. Representative masses include fluid intensity lesion adjacent to a joint or bursa, possibly a septated ganglion cyst, or fibrous tissue signal lesions in relation to fascia and muscles, e.g., classic palmar or plantar fibromatosis [29] (moderately-markedly hypointense on T1W and T2W imaging), or intramuscular lesion such as a myxoma [6, 40]. Intra-muscular myxoma can be a pathognomonic diagnosis [61] but may show heterogeneous enhancement, that is why it is placed in STRADS III and not II or IV. Plantar fibroma is placed in ST-RADS II as it is a classic benign diagnosis with a pea-shaped enhancing nodule in relation to central cord of plantar fascia. Fibromatosis is however placed in ST-RADS III as these can be larger, sheet-like, multifocal, locally aggressive (rarely metastasizing), and can mimic low grade sarcoma [34]. In addition, ST-RADS guide is not intended to match a particular histology with a particular ST-RAD grade as the histology wouldn't be known prospectively but is envisioned as a system that can be of practical use and which can be tested prospectively refined as more experience is garnered over the years. Other tumors or tumor-like lesions include those with typical imaging features, e.g., lipoma with metaplastic calcification or ossification, myositis ossificans (history of trauma, internal hemorrhage, marbled muscle-like appearance of the mass, and developing peripheral calcification on the corresponding radiograph or CT), benign peripheral nerve sheath tumors $[30,53]$ (target or fascicular sign, absent peritumoral edema or necrosis, length $<5 \mathrm{~cm}$, underlying schwannomatosis, absent rapid growth or new or sudden neurological deficit or excessive pain), synovial chondromatosis, tenosynovial giant cell tumor (TSGCT), Desmoid, and angiolipoma [19]. Post-contrast imaging of such lesions may exhibit no enhancement or thin (< 2 mm) peripheral and/or septal enhancement, such as a ganglion cyst or bursitis, or variable enhancement with other lesions. DWI, if obtained, exhibits moderate-marked hyperintensity of the lesion on DWI and mild-moderate hyperintensity on ADC images, with generally a mean ADC value $=1.2-$ $2.0 \times 10-3 \mathrm{~mm} 2 / \mathrm{s}$. Caution needs to be exercised with certain lesions, such as TSGCT and myxoid lesions [34]. TSGCT typically shows hypointense to moderately hyperintense DWI signal, and mean ADC can be low, varying from $0.8-1.3 \times 10^{-3} \mathrm{~mm} / \mathrm{s}$ [3]. Both benign and malignant myxoid tumors commonly exhibit high ADC values [36].

ST-RADS IV was used for potentially malignant, but indeterminate tumors, and the suspicion for malignancy is more than $2 \%$ and less than $50 \%$. The recommendation is tissue biopsy or short-term follow up in 4-6 weeks, and regular interval follow-up for upto 2 years. Tumors in this category may exhibit mixed intensity on MR imaging, a solid appearance, however less than $5 \mathrm{~cm}$ maximum length, or a lipomatous lesion with multiple septations without a solid focal nodule or myxoid change. Representative tumors include atypical lipomatous lesion [19, 26], solitary fibrous tumor, and Gardner fibroma [29]. On post-contrast imaging, there is variable enhancement. DWI, if obtained, exhibits moderate-marked hyperintensity of the lesion on DWI and mild-moderate hyperintensity on ADC images, with generally a mean ADC value $>1.1 \times 10-3$ mm $2 / s[3,9$, 62]

ST-RADS $V$ was used for probably malignant tumors where tissue diagnosis is recommended. The probability of malignancy in this group of tumors is $50 \%$ or more. On MRI, these tumors exhibit mixed intensity and a solid mass, or a lipomatous lesion containing multiple thick septations or solid nodule (s), and/or myxoid changes or a lipid poor T2 hyperintense enhancing mass. Representative tumors in this category include malignant peripheral nerve sheath tumor [30,53], synovial sarcoma [24, 50], undifferentiated pleomorphic sarcoma, myxofibrosarcoma [25], melanoma, and lymphoma [43]. These lesions show variable and solid enhancement with diffusion restriction and mean $A D C$ values $=<1.1 \times 10^{-3} \mathrm{~mm}^{2} / \mathrm{s}[9]$. As with other myxoid tumors, myxoid sarcomas typically have areas of higher mean ADC [42].

ST-RADS VI was used for a known biopsy-proven malignancy or recurrent malignancy in the tumor bed prior to definitive therapy.

Recommendations include surgical excision or further treatment as clinically appropriate. Solid nodule or residual/growing mass with imaging features like the pre-intervention lesion in the tumor bed suggests tumor recurrence. Post-contrast imaging typically shows solid nodular enhancement or enhancement similar to the tumor prior to intervention in such cases $[10,15,39]$. DWl, if obtained, shows diffusion restriction and mean $A D C<1.1 \times 10^{-3} \mathrm{~mm}^{2} / \mathrm{s}$ or similar to that of the pre-intervention tumor [15].

The consensus document was edited, shared electronically among experienced radiologists with sarcoma imaging, and discussed during conference calls. Once agreed upon, multi-reader testing was performed at all three sites. Instead of reviewers guessing qualitatively during readouts and mentioning likelihood of malignancy on a Likert scale as unlikely, possible, probable, highly likely, etc., quantitative numbers were presented to the reviewers to remind them about the categories as has been validated in the BI-RADS system and how they would have practically reported such studies, e.g. is it significantly indeterminate with still less than $50 \%$ probability that one could present a choice of tissue sampling or a short-term follow-up versus more than $50 \%$ chance of malignancy that one should obtain tissue sampling. The goal of ST-RADS is a dynamic guideline document that may be refined as more evidence is collected over time.

For validation and testing purposes, commonly encountered tumors in all three described categories were used: adipocytic tumors, T2hyperintense and T2-hypontense tumors encompassing a mixture of a wide spectrum of common and uncommon histologies as identified from 
the WHO classification [54]. The hyperintense or hypointense categories were based on predominant tumor appearance on T2W imaging, meaning at least $50 \%$ or more of tumor appeared hyperintense or hypointense, respectively.

\section{Data collection and rating procedures}

A random sample of soft tissue tumors with 'complete' MR imaging sets of adipocytic and T2-hyperintense tumors and tumor-like lesions with proven histopathological diagnoses were collected and shared among the three institutes using Microsoft PowerPoint presentations (Office 365, Microsoft, Seattle, WA) via online meetings. The data sets were anonymized, and the readers of each site were presented with tumors from the other site. The tumors were displaced in the entirety with most-representative images. The readers were blinded to the final histological diagnosis and the interpretation of the other readers. A musculoskeletal fellow at UTSW controlled all data and compiled all interpretations in an Excel database (Windows 10, Microsoft, Redwood, WA). DWI and ADC images were available as supplemental images in a few cases, specifically four T2-hyperintense and one adipocytic tumors.

The principal investigator conducted a training session on three separate occasions to standardize the understanding of the ST-RADS consensus document before independent scoring. A total of 200 soft tissue tumors (100 adipocytic tumors, 50 T2-hyperintense tumors, and 50 T2-hyponitense tumors) were evaluated (Table. 3). Eight Musculoskeletal radiologists evaluated the studies with their attending level experience ranging from 2 years post-fellowship to more than 30 years of interpreting MR imaging of soft tissue tumors (Table. 4).

\section{Statistical Analysis}

Intraclass correlation coefficient (ICC $(2,1)$ ) with a mixed-effects model was used to assess inter-reader agreement and the reliability of the guideline system. Median ST-RADS from readers use to assess diagnostic performance. Areas under the receiver operating curve (AUC) were calculated. Sensitivity and specificity were also calculated with I/II/III as benign and IV/V as malignant with final histology diagnosis bases on biopsy and/or surgery serving as the reference standard. All analyses were done in R 4.0.2 (Vienna, Austria) by an expert statistician from the primary institution.

The following interpretation of ICC was used: Excellent Agreement: 0.75 - 1.00; Good Agreement: 0.60 - 0.75 ; Fair Agreement: 0.40 - 0.60; and Poor Agreement: < 0.40 [11].

\section{Results}

\section{Tumor types}

There were 200 soft tissue tumors of various histology, including 100 adipocytic (53 benign and 47 malignant), 50 T2-hyperintense tumors (35 benign and 15 malignant), and 50 T2-hypointense masses (25 benign and 25 malignant). The histopathological diagnoses tested are shown in Table. 3. Few representative examples are shown in Fig. 1-4.

\section{Reliability of the System}

There was a good inter-reader agreement with $\mathrm{ICC}=0.72$ [95\% $\mathrm{Cl}=0.64-0.79]$ for adipocytic tumors and 0.69 [95\% $\mathrm{Cl}=0.59-0.70]$ for $\mathrm{T} 2$ hyperintense masses and fair, 0.48 [95\% $\mathrm{Cl}=0.35-0.62]$ for T2-hypointense tumors. Stratified ICC by years of experience ( $<10$ vs $\geq 10$ years) were also reported (Tables. 5, 6, 7).

\section{Diagnostic performance}

AUC was $0.89(0.82,0.95)$ for adipocytic masses, $0.82(0.72,0.92)$ for T2-hyperintense masses and $0.79(0.67,0.91)$ for T2-hypointense masses (Fig. 5, 6). Using ST_RADS $\geq 4$ as a threshold for malignancy, the sensitivity and specificity of the system for detection of malignancy in adipocytic masses were $96 \%$ and $63 \%$, T2-hyperintense masses were $93 \%, 71 \%$, and T2-hypointense masses were $64 \%$ and $84 \%$, respectively.

\section{Discussion}

After the initial success of BI-RADS, which was first introduced in 1993, followed several reporting and data systems, e.g. for liver, brain, and thyroid tumors, all with a common goal of addressing the lack of uniformity in reporting imaging findings [4]. So far, there are nine established RADS and several new in different stages of development [2], including CO-RADs, to assess the probability of pulmonary involvement with the Covid 19 virus [41]. For soft tissue tumors, the development of a standardized guideline can serve as a useful template for a radiologist for MR

Page 5/21 
interpretation and future management of such patients. According to Datir et al, large tumors $(>5 \mathrm{~cm})$ that are deeply seated indicate a higher malignancy risk and should be biopsied [14]. A tumor classification on MR imaging merely by location and size is certainly not enough and results in much ambiguity in reporting soft tissue tumors. Thus, this study was performed to validate and fulfill the need for a standardized guideline to facilitate soft tissue tumor categorization, thereby allowing specific management recommendations. The tumors used for this system included both common and uncommon histologies encountered in daily practice. In addition, unknown imaging cases were used from three tertiary care centers to minimize confirmation bias and memory effects.

The ST-RADS creation followed the methodology of the prototype "BI-RADS" [5] by using an expert consensus to develop the system followed by a validation step. The system showed good AUC for both adipocytic (0.89) and T2-hyperintense and T2-hypointense lesions (0.82, 0.79). The final score for each set of tumors was also reproducible by readers of different experience levels. The accuracy of malignancy detection in soft tissue tumors by MRI has been reported to range from 44-85\%, and the results can be variable due to differences in reader experience and complexity of cases [21, 63-65]. In this large multicenter prospective study evaluating 548 untreated and proven soft tissues masses, a consensus MRI interpretation by two radiologists based on qualitative features yielded an overall accuracy of $85 \%$, sensitivity of $93 \%$, and specificity of $82 \%$ for the categorization of soft tissue masses as benign or malignant. Another study by Emery et al. evaluated 225 cases of soft tissue tumors and showed an accuracy of $44 \%$ with a sensitivity of $78 \%$ and $89 \%$ specificity in differentiating benign from malignant tumors on MRI [35]. ST-RADS showed good ROC in our study validating the classification system. The overall sensitivity for detecting malignancy using the ST-RADS scoring system for adipocytic and T2-hyperintense masses is higher when compared to the sensitivity of the BIRADSs system (87.2\%). However, The BIRADS scoring system specificity (90.1\%) outperforms the ST-RADS system [45]. The ROC curve and AUC currently are the current standard assessment of any given diagnostic test's accuracy. The closer the value to 1, the more accurate the test is, with the best results above 0.9. The AUC in BI-RADS is 0.93 , only slightly higher than this study's results for adipocytic tumors and like T2- hyperintense masses. This implies that both systems have a comparable moderate to high degree of accuracy in detecting malignancy. It should also be noted that compared to tumors of the breast and prostate, soft tissue tumors however represent a much larger group with multiple benign, intermediate, and malignant entities (WHO), and the individual treatment strategies show a higher variability for benign as well as malignant tumors.

There was a good inter-reader agreement for both categories of tumors. The ICCs were even better for adipocytic tumors, possibly due to the wide variety of histologies among T2-hyperintense and T-hypointense lesions. The average ICC amongst adipocytic and T2-hyperintense tumor types was 0.7 (good) among 8 MSK trained radiologist, similar to Cietto et al. who reported average intrareader kappa of 0.71 based on 12 radiologists interpreting mammograms following the BIRADS scoring system [7, 28]. It was fair for T2-hypointense lesions. To the best of our knowledge, inter-reader agreement for differentiating benign and malignant soft tissue masses on MRI has not been reported before and larger available studies in this domain only used consensus opinion to determine the diagnostic accuracy. We used DWI as a supplementary tool in this study, as it is not routinely used in all practice settings. DWI might improve the ICCs for T2-hyperintense tumors if used uniformly in all cases $[3,9]$. ST-RADS is designed to be a dynamic or living document that will continue to be refined based on wider user experience with DWI and feedback.

We found that the categorization of soft tissues utilizing the ST-RADS was an effective way to describe imaging findings and characterize lesions. Like other RADS, the proposed reporting structure provides defined categories based on the probability of malignancy for final assessment and suggestions for further management. This will allow the reader to apply consistent terminology and reduce imaging interpretation variability and errors. The standardized reporting terminology can facilitate better communication and reduce confusion among physicians and patients.

Another important strength was that this study was a tertiary multicenter collaborative study involving eight radiologists with different experience levels in tumor imaging interpretation, ranging between 2 years to $>30$ years attending level expertise. None of the radiologists had previously seen the cases presented to them, and the pathologic diagnosis was not known to them at the time of interpretation. We believe having tested this system with readers of different experience levels, it will be applicable to both general radiologists and experienced oncoradiologists. The younger reader performed better, and it might be the case that they were more diligent and cautious in evaluations, however all readers were fellowship trained musculoskeletal radiologists who routinely conduct tumor boards.

The categorical reporting system would be advantageous in the management of indeterminate soft tissue lesions by providing clear guidelines for further management. It can help determine which lesion needs an invasive procedure, such as a biopsy or surgery, thereby saving time and effort by avoiding unnecessary procedures. In addition, this system will also facilitate data collection and provide new opportunities for education, quality assurance, peer review, and research.

This study has some limitations. The cases were presented by PowerPoint presentations among institutions. While this allowed for easy anonymization and data sharing, real-time windowing and image scrolling were not available, which may have limited detailed evaluation. However, it was ensured that representative sections, margins, and extents of tumors were included in the imaging presentation. Ideally, this system should be tested and re-tested prospectively before its widespread use. This system, however, followed the processes used during the validation of other existent guidelines, such as BI-RADS and LI-RADS. It is hoped that more widespread use of ST-RADS will lead to further 
validation, refinement, and acceptance. Furthermore, future works will include incorporating advanced imaging sequences, including DWI, dynamic contrast imaging, etc. as has been done for prostate cancer guideline (PI-RADS system).

\section{Conclusion}

ST-RADS guideline using standardized terminology stratifies musculoskeletal tumors into benign and malignant categories and provides management strategy. This MRI-based guideline is meant to be a "dynamic" document that can be further refined and updated in response to future user feedback and as new scientific data becomes available.

\section{Abbreviations}

AUC

Area under the curve

ADC

Apparent diffusion coefficient

DWI

Diffusion weighted imaging

ICC

Intraclass correlation

ST-RADS

Soft-tissue tumor reporting and data system

TSGCT

Tenosynovial giant cell tumor

\section{Declarations}

\section{Funding: None}

Competing interests: None

\section{Ethical review committee statement, consent for publication and availability of data:}

Retrospective, cross-sectional multi-institutional and multi-reader study. Anonymized MRI studies from different institutions as part of retrospective local Institutional review boards (UTSW IRB- STU 112017- 003), and the informed consent was waived by UTSW ethics committee. No data use agreement was required as per UTSW IRB as no HIPAA information was used. All methods were carried out in accordance with relevant guidelines and regulations. All experimental protocols were approved by a named institutions and/or licensing committee.

This work was performed at the Musculoskeletal subdivision of the Radiology departments of UT Southwestern Medical Center, Dallas, Texas, USA, University of Arkansas for Medical Sciences, Little Rock, Arkansas, USA and The University of Texas M. D. Anderson Cancer Center, Houston, Texas, USA

The data of readers interpretations and statistics can be made available as required.

Consent for publication: not applicable.

Acknowledgements: None

\section{Author contributions:}

Avneesh Chhabra M.D-Study design, manuscript drafting and editing, guarantor of the study

Oganes Ashikyan M.D- reader and manuscript editing

Raghu RatakondaM.D and Marwa Zaid M.D, FFR-RCSI- study organizer, collation of cases and reads, manuscript editing

Gitanjali Bajaj M.D- reader and manuscript editing

Uma ThakurM.D- reader and manuscript editing

Parham PezeshkM.D- reader and manuscript editing 
Yin XiPh.D- statistical analysis, study design and manuscript editing

Alexandra CallanM.D- study design and editing

William MurphyM.D- reader, study design and manuscript editing

Rajendra Kumar M.D, F.A.C.R- reader, study design and manuscript editing

Behrang Amini M.D, Ph.D- reader, study design and manuscript editing, co- guarantor of the study

\section{Conflict of interest:}

No commercial associations (eg, consultancies, stock ownership, equity interest, patent/licensing arrangements, etc) that might pose a conflict of interest in connection with the submitted article.

Avneesh Chhabra- Receives royalties from Jaypee and Wolters. He also serves as a consultant with ICON Medical and Treace Medical Concepts, Inc. Speaker for Siemens. Medical advisor for Image biopsy lab, Inc. The author does not report any conflict of interest.

Oganes Ashikyan - No relevant disclosures. No conflict of interest.

Raghu Ratakonda - No disclosures. No conflict of interest.

Gitanjali Bajaj - No relevant disclosures. No conflict of interest.

Uma Thakur - No relevant disclosures. No conflict of interest.

Parham Pezeshk - No relevant disclosures. No conflict of interest.

Yin Xi - No relevant disclosures. No conflict of interest.

Marwa Zaid - No disclosures. No conflict of interest.

Alexandra Callan- No disclosures. No conflict of interest.

William Murphy - No relevant disclosures. No conflict of interest.

Rajendra Kumar - No relevant disclosures. No conflict of interest.

Behrang Amini - No relevant disclosures. No conflict of interest.

\section{References}

1. Alamanda VK, Delisca GO, Mathis SL, Archer KR, Ehrenfeld JM, Miller MW et. al. The financial burden of reexcising incompletely excised soft tissue sarcomas: a cost analysis. Annals of surgical oncology. 2013;20:2808-2814.

2. An JY, Unsdorfer KM, Weinreb JC. BI-RADS, C-RADS, CAD-RADS, LI-RADS, Lung-RADS, NI-RADS, O-RADS, PI-RADS, TI-RADS: Reporting and Data Systems. RadioGraphics. 2019;39:1435-1436.

3. Ashikyan O, Chalian M, Moore D, Xi Y, Pezeshk P, Chhabra A. Evaluation of giant cell tumors by diffusion weighted imaging-fractional ADC analysis. Skeletal Radiol. 2019;48:1765-1773.

4. Baker JA, Kornguth PJ, Floyd Jr C. Breast imaging reporting and data system standardized mammography lexicon: Observer variability in lesion description. AJR. American journal of roentgenology. 1996;166:773-778.

5. Balleyguier C, Ayadi S, Van Nguyen K, Vanel D, Dromain C, Sigal R. BIRADS ${ }^{\mathrm{TM}}$ classification in mammography. European journal of radiology. 2007;61:192-194.

6. Bancroft LW, Kransdorf MJ, Menke DM, O'Connor MI, Foster WC. Intramuscular myxoma: characteristic MR imaging features. AJR Am J Roentgenol. 2002;178:1255-1259.

7. Boyd NF, Wolfson C, Moskowitz M, Carlile T, Petitclerc C, Ferri HA et. al. Observer variation in the classification of mammographic parenchymal patterns. Journal of chronic diseases. 1986;39:465-472.

8. Brisson M, Kashima T, Delaney D, Tirabosco R, Clarke A, Cro S et. al. MRI characteristics of lipoma and atypical lipomatous tumor/welldifferentiated liposarcoma: retrospective comparison with histology and MDM2 gene amplification. Skeletal radiology. 2013;42:635-647.

9. Chhabra A, Ashikyan O, Slepicka C, Dettori N, Hwang H, Callan A, et. al. Conventional MR and diffusion-weighted imaging of musculoskeletal soft tissue malignancy: correlation with histologic grading. Eur Radiol. 2019;29:4485-4494.

Page $8 / 21$ 
10. Chou SS, Hippe DS, Lee AY, Scherer K, Porrino JA, Davidson DJ, et. al. Gadolinium Contrast Enhancement Improves Confidence in Diagnosing Recurrent Soft Tissue Sarcoma by MRI. Acad Radiol. 2017;24:615-622.

11. Cicchetti DV. Guidelines, criteria, and rules of thumb for evaluating normed and standardized assessment instruments in psychology. Psychological assessment. 1994;6:284.

12. Cohen EK, Kressel HY, Perosio T, Burk DL, Jr., Dalinka MK, Kanal E et. al. MR imaging of soft-tissue hemangiomas: correlation with pathologic findings. AJR Am J Roentgenol. 1988;150:1079-1081.

13. Cormier JN, Pollock RE. Soft tissue sarcomas. CA: a cancer journal for clinicians. 2004;54:94-109.

14. Datir A, James SL, Ali K, Lee J, Ahmad M, Saifuddin A. MRI of soft-tissue masses: the relationship between lesion size, depth, and diagnosis. Clin Radiol. 2008;63:373-378; discussion 379-380.

15. Del Grande F, Subhawong T, Weber K, Aro M, Mugera C, Fayad LM. Detection of soft-tissue sarcoma recurrence: added value of functional MR imaging techniques at 3.0 T. Radiology. 2014;271:499-511.

16. Dhagat PK, Jain M, Farooq A. MRI evaluation of soft tissue vascular malformations: Indian J Radiol Imaging. 2020 Apr-Jun;30(2):184-9. doi: 10.4103/ijri.IJRI_439_19. Epub 2020 Jul 13.

17. Drevelegas A, Pilavaki M, Chourmouzi D. Lipomatous tumors of soft tissue: MR appearance with histological correlation. European journal of radiology. 2004;50:257-267.

18. Frassica FJ, Khanna JA, McCarthy EF. The role of MR imaging in soft tissue tumor evaluation: perspective of the orthopedic oncologist and musculoskeletal pathologist. Magnetic resonance imaging clinics of North America. 2000;8:915-927.

19. Gaskin CM, Helms CA. Lipomas, lipoma variants, and well-differentiated liposarcomas (atypical lipomas): results of MRI evaluations of 126 consecutive fatty masses. AJR Am J Roentgenol. 2004;182:733-739.

20. Gerrand $\mathrm{CH}$, Rankin K. The hazards of biopsy in patients with malignant primary bone and soft-tissue tumors. Classic Papers in Orthopaedics: Springer; 2014:491-493.

21. Gielen JL, De Schepper AM, Vanhoenacker F, Parizel PM, Wang XL, Sciot R et. al. Accuracy of MRI in characterization of soft tissue tumors and tumor-like lesions. A prospective study in 548 patients. Eur Radiol. 2004;14:2320-2330.

22. Gustafson P. Soft tissue sarcoma: epidemiology and prognosis in 508 patients. Acta Orthopaedica Scandinavica. 1994;65:2-31.

23. Jeon JY, Chung HW, Lee MH, Lee SH, Shin MJ. Usefulness of diffusion-weighted MR imaging for differentiating between benign and malignant superficial soft tissue tumours and tumour-like lesions. Br J Radiol. 2016;89:20150929.

24. Jones BC, Sundaram M, Kransdorf MJ. Synovial sarcoma: MR imaging findings in 34 patients. AJR Am J Roentgenol. 1993;161:827-830.

25. Kaya M, Wada T, Nagoya S, Sasaki M, Matsumura T, Yamaguchi T et. al. MRI and histological evaluation of the infiltrative growth pattern of myxofibrosarcoma. Skeletal Radiol. 2008;37:1085-1090.

26. Kransdorf MJ, Bancroft LW, Peterson JJ, Murphey MD, Foster WC, Temple HT. Imaging of fatty tumors: distinction of lipoma and welldifferentiated liposarcoma. Radiology. 2002;224:99-104.

27. Kransdorf MJ, Murphey MD. Imaging of soft tissue tumors: Lippincott williams \& wilkins; 2006.

28. Lee AY, Wisner DJ, Aminololama-Shakeri S, Arasu VA, Feig SA, Hargreaves J, et. al. Inter-reader variability in the use of BI-RADS descriptors for suspicious findings on diagnostic mammography: a multi-institution study of 10 academic radiologists. Academic Radiology. 2017;24:60-66.

29. Lee JC, Thomas JM, Phillips S, Fisher C, Moskovic E. Aggressive fibromatosis: MRI features with pathologic correlation. AJR Am J Roentgenol. 2006;186:247-254.

30. Li CS, Huang GS, Wu HD, Chen WT, Shih LS, Lii JM et. al. Differentiation of soft tissue benign and malignant peripheral nerve sheath tumors with magnetic resonance imaging. Clin Imaging. 2008;32:121-127.

31. Marom EM, Helms CA. Fibrolipomatous hamartoma: pathognomonic on MR imaging. Skeletal Radiol. 1999;28:260-264.

32. Mellado J, Salvado E, Camins A, Ramos A, Merino X, Calmet J et. al. Fluid collections and juxta-articular cystic lesions of the shoulder: spectrum of MRI findings. European radiology. 2002;12:650-659.

33. Mettlin C, Priore R, Rao U, Gamble D, Lane W, Murphy P. Results of the national soft-tissue sarcoma registry. J Surg Oncol. 1982;19:224-227.

34. Morrison WB, Schweitzer ME, Wapner KL, Lackman RD. Plantar fibromatosis: a benign aggressive neoplasm with a characteristic appearance on MR images. Radiology. 1994;193:841-845.

35. Moulton JS, Blebea JS, Dunco DM, Braley SE, Bisset GS, 3rd, Emery KH. MR imaging of soft-tissue masses: diagnostic efficacy and value of distinguishing between benign and malignant lesions. AJR Am J Roentgenol. 1995;164:1191-1199.

36. Nagata S, Nishimura H, Uchida M, Sakoda J, Tonan T, Hiraoka K et. al. Diffusion-weighted imaging of soft tissue tumors: usefulness of the apparent diffusion coefficient for differential diagnosis. Radiation medicine. 2008;26:287-295. 
37. Obaid H, Vassos N, Adams SJ, Bryce R, Donuru A, Sinclair N. Development of a risk assessment model to differentiate malignant and benign musculoskeletal soft-tissue masses on magnetic resonance imaging. Journal of Medical Imaging and Radiation Oncology. 2020;64:9-17.

38. Obenauer S, Hermann K, Grabbe E. Applications and literature review of the BI-RADS classification. European radiology. 2005;15:1027-1036.

39. Park JW, Yoo HJ, Kim HS, Choi JY, Cho HS, Hong SH et. al. MRI surveillance for local recurrence in extremity soft tissue sarcoma. Eur J Surg Oncol. 2019;45:268-274.

40. Peterson KK, Renfrew DL, Feddersen RM, Buckwalter JA, el-Khoury GY. Magnetic resonance imaging of myxoid containing tumors. Skeletal Radiol. 1991;20:245-250.

41. Prokop M, van Everdingen W, van Rees Vellinga T, Quarles van Ufford H, Stöger L, Beenen L et al.. CO-RADS: A Categorical CT Assessment Scheme for Patients Suspected of Having COVID-19-Definition and Evaluation. Radiology. 2020;296:E97-e104.

42. Subhawong TK, Jacobs MA, Fayad LM. Insights into quantitative diffusion-weighted MRI for musculoskeletal tumor imaging. AJR Am J Roentgenol. 2014;203:560-572.

43. Suresh S, Saifuddin A, O'Donnell P. Lymphoma presenting as a musculoskeletal soft tissue mass: MRI findings in 24 cases. Eur Radiol. 2008;18:2628-2634.

44. Tamimi Mariño I, Sesma Solis P, Pérez Lara A, Martinez Malo J, Vazquez ML, Tamimi F. Sensitivity and positive predictive value of magnetic resonance imaging in the diagnosis of elastofibroma dorsi: review of fourteen cases. J Shoulder Elbow Surg. 2013;22:57-63.

45. Tan Y, Liu S, Ma L, Du W. Difference Analysis of Sensitivity of BI-RADS Classification of Breast Mass with Different Pathological Types. Indian Journal of Pharmaceutical Sciences. 2019:50-57.

46. Teixeira PA, Gay F, Chen B, Zins M, Sirveaux F, Felblinger J et. al. Diffusion-weighted magnetic resonance imaging for the initial characterization of non-fatty soft tissue tumors: correlation between T2 signal intensity and ADC values. Skeletal Radiol. 2016;45:263-271.

47. Toro JR, Travis LB, Wu HJ, Zhu K, Fletcher CD, Devesa SS. Incidence patterns of soft tissue sarcomas, regardless of primary site, in the surveillance, epidemiology and end results program, 1978-2001: an analysis of 26,758 cases. International journal of cancer. 2006;119:2922-2930.

48. Tsai TS, Evans HA, Donnelly LF, Bisset GS, 3rd, Emery KH. Fat necrosis after trauma: a benign cause of palpable lumps in children. AJR Am J Roentgenol. 1997;169:1623-1626.

49. Tsubakimoto M, Yamashiro T, Tsuchiya N, Okada M, Maehara H, Kitsukawa K et. al. MRI findings and demographics of elastofibroma dorsi: assessment of diffusion-weighted imaging and contrast enhancement patterns. Acta Radiol. 2018;59:709-715.

50. Valenzuela RF, Kim EE, Seo JG, Patel S, Yasko AW. A revisit of MRI analysis for synovial sarcoma. Clin Imaging. 2000;24:231-235.

51. van Vliet M, Kliffen M, Krestin G, Van Dijke C. Soft tissue sarcomas at a glance: clinical, histological, and MR imaging features of malignant extremity soft tissue tumors. European radiology. 2009;19:1499-1511.

52. Vassalou EE, Zibis AH, Raoulis VA, Tsifountoudis IP, Karantanas AH. Morel-Lavallee Lesions of the Knee: MRI Findings Compared With Cadaveric Study Findings. AJR Am J Roentgenol. 2018;210:W234-W239.

53. Wasa J, Nishida Y, Tsukushi S, Shido Y, Sugiura H, Nakashima $\mathrm{H}$ et al. MRI features in the differentiation of malignant peripheral nerve sheath tumors and neurofibromas. AJR Am J Roentgenol. 2010;194:1568-1574.

54. WHO Editorial Board. WHO Classification of Tumours of Soft Tissue and Bone: IARC; 2020.

55. Griffith JF, Yip SWY, Hung EHY, Fong RCW, Leung J, Ng AWH et al. Accuracy of ultrasound in the characterisation of deep soft tissue masses: a prospective study. Eur Radiol. 2020 Nov;30(11):5894-5903. doi: 10.1007/s00330-020-07002-5. Epub 2020 Jun 26. PMID: 32591891.

56. Gruber L, Loizides A, Luger AK, Glodny B, Moser P, Henninger B et al. Soft-Tissue Tumor Contrast Enhancement Patterns: Diagnostic Value and Comparison Between Ultrasound and MRI. AJR Am J Roentgenol. 2017 Feb;208(2):393-401. doi: 10.2214/AJR.16.16859. Epub 2016 Dec 13. PMID: 27959625.

57. Del Grande F, Ahlawat S, Subhawong T, Fayad LM. Characterization of indeterminate soft tissue masses referred for biopsy: What is the added value of contrast imaging at 3.0 tesla? J Magn Reson Imaging. 2017 Feb;45(2):390-400. doi: 10.1002/jmri.25361. Epub 2016 Jul 15. Erratum in: J Magn Reson Imaging. 2017 Apr;45(4):1246. PMID: 27417663.

58. Noebauer-Huhmann IM, Weber MA, Lalam RK, Trattnig S, Bohndorf K, Vanhoenacker F et. al. Soft Tissue Tumors in Adults: ESSR-Approved Guidelines for Diagnostic Imaging. Semin Musculoskelet Radiol. 2015 Dec;19(5):475-82. doi: 10.1055/s-0035-1569251. Epub 2015 Dec 22. Erratum in: Semin Musculoskelet Radiol. 2015 Dec;19(5):e1. PMID: 26696086.

59. Berquist TH, Dalinka MK, Alazraki N, Daffner RH, DeSmet AA, el-Khoury GY et.al. Soft tissue masses. American College of Radiology. ACR Appropriateness Criteria. Radiology. 2000 Jun;215 Suppl:255-9. PMID: 11037435.

60. Obara P, McCool J, Kalva SP, Majdalany BS, Collins JD, Eldrup-Jorgensen J, et. al. Expert Panel on Vascular Imaging, ACR Appropriateness Criteria ${ }^{\circledR}$ Clinically Suspected Vascular Malformation of the Extremities. J Am Coll Radiol. 2019 Nov;16(11S):S340-S347. doi: 
10.1016/j.jacr.2019.05.013. PMID: 31685102.

61. Chhabra A, Soldatos T. Soft-tissue lesions: when can we exclude sarcoma? AJR Am J Roentgenol. 2012 Dec;199(6):1345-57. doi: 10.2214/AJR.12.8719. PMID: 23169729.

62. Ahlawat S, Khandheria P, Del Grande F, Morelli J, Subhawong TK, Demehri S et. al. Interobserver variability of selective region-of-interest measurement protocols for quantitative diffusion weighted imaging in soft tissue masses: Comparison with whole tumor volume measurements. J Magn Reson Imaging. 2016 Feb;43(2):446-54. doi: 10.1002/jmri.24994. Epub 2015 Jul 14. PMID: 26174705.

63. Crombé A, Marcellin PJ, Buy X, Stoeckle E, Brouste V, Italiano A et. al. Soft-Tissue Sarcomas: Assessment of MRI Features Correlating with Histologic Grade and Patient Outcome. Radiology. 2019 Jun;291(3):710-721. doi: 10.1148/radiol.2019181659. Epub 2019 Apr 9. PMID: 30964422.

64. Chung WJ, Chung HW, Shin MJ, Lee SH, Lee MH, Lee JS et. al. MRI to differentiate benign from malignant soft-tissue tumours of the extremities: a simplified systematic imaging approach using depth, size and heterogeneity of signal intensity. Br J Radiol. 2012 Oct;85(1018):e831-6. doi: 10.1259/bjr/27487871. Epub 2012 May 2. PMID: 22553293; PMCID: PMC3474004.

65. McKeon KE, Wright BT, Lee DH. Accuracy of MRI-based Diagnoses for Distal Upper Extremity Soft Tissue Masses. J Hand Microsurg. 2015 Jun;7(1):61-6. doi: 10.1007/s12593-015-0174-6. Epub 2015 Jan 15. PMID: 26078505; PMCID: PMC4461636.

\section{Tables}

Table 1: ST-RADS Classification and Guideline.

\begin{tabular}{|c|c|c|c|}
\hline Classification & Category & Management & $\begin{array}{l}\text { Likelihood of } \\
\text { malignancy }\end{array}$ \\
\hline ST-RADS 0 & Incomplete imaging & Recall for additional imaging and/or await prior examinations. & $\mathrm{N} / \mathrm{A}$ \\
\hline ST-RADS I & No lesion identified & No further imaging follow-up & Essentially $0 \%$ \\
\hline ST-RADS II & Definitely benign & Follow-up as per clinical team recommendations & Essentially $0 \%$ \\
\hline ST-RADS III & Probably benign & $\begin{array}{l}\text { Follow-up in } 3 \text { months, six months, one year, and two years or < } \\
2 \text { years / shorter-term follow-up if the lesion resolves or significantly } \\
\text { regresses }\end{array}$ & $\begin{array}{l}\text { Less than or } \\
\text { equal to } 2 \%\end{array}$ \\
\hline ST-RADS IV & $\begin{array}{l}\text { Suspicious for malignancy or } \\
\text { indeterminate }\end{array}$ & $\begin{array}{l}\text { Tissue diagnosis or follow-up in } 4-6 \text { weeks interval, and regular } \\
\text { interval follow-up for upto } 2 \text { years }\end{array}$ & $\begin{array}{l}\text { More than } 2 \% \\
\text { and less than } \\
50 \%\end{array}$ \\
\hline ST-RADS V & Highly suggestive of malignancy & Tissue diagnosis & $\begin{array}{l}\text { More than or } \\
\text { equal to } 50 \%\end{array}$ \\
\hline ST-RADS VI & $\begin{array}{l}\text { Known biopsy-proven malignancy } \\
\text { or recurrent malignancy in the } \\
\text { tumor bed }\end{array}$ & Surgical excision or further treatment as clinically appropriate & $\mathrm{N} / \mathrm{A}$ \\
\hline
\end{tabular}

Table 2: ST-RADS and Tumors based on WHO classification 


\begin{tabular}{|c|c|c|c|c|c|}
\hline Classification & $\begin{array}{l}\text { Adipocytic } \\
\text { masses }\end{array}$ & Vascular tumors & Nerve sheath tumors & $\begin{array}{l}\text { Fibroblastic/myoblastic } \\
\text { tumors }\end{array}$ & $\begin{array}{l}\text { Miscellaneous } \\
\text { tumors }\end{array}$ \\
\hline ST-RADS 0 & - & - & - & - & - \\
\hline ST-RADS I & $\begin{array}{l}\text { No lesion } \\
\text { identified }\end{array}$ & No lesion identified & No lesion identified & No lesion identified & No lesion identified \\
\hline ST-RADS II & $\begin{array}{l}\text { Lipomatosis, } \\
\text { Lipoma, Fat } \\
\text { necrosis }\end{array}$ & $\begin{array}{l}\text { Hemangioma, } \\
\text { Angiomatosis, } \\
\text { Lymphangioma }\end{array}$ & & $\begin{array}{l}\text { Elastofibroma } \\
\text { Fibromatosis colli } \\
\text { Palmar / plantar } \\
\text { fibromatosis }\end{array}$ & Glomus tumor \\
\hline ST-RADS III & $\begin{array}{l}\text { Lipoblastoma } \\
\text { Angiolipoma } \\
\text { Myolipoma of } \\
\text { soft tissue } \\
\text { Chondroid } \\
\text { lipoma } \\
\text { Extra-renal } \\
\text { angiomyolipoma } \\
\text { Extra-adrenal } \\
\text { extra-adrenal } \\
\text { myelolipoma } \\
\text { Spindle cell / } \\
\text { pleomorphic } \\
\text { lipoma } \\
\text { Hibernoma }\end{array}$ & $\begin{array}{l}\text { Hemangioma, } \\
\text { Angiomatosis, } \\
\text { Lymphangioma }\end{array}$ & $\begin{array}{l}\text { Schwannoma, } \\
\text { Melanotic } \\
\text { schwannoma, } \\
\text { Neurofibroma, } \\
\text { Plexiform } \\
\text { neurofibroma, } \\
\text { Perineurioma, } \\
\text { Granular cell tumor, } \\
\text { Dermal nerve sheath } \\
\text { myxoma, } \\
\text { Ectopic meningioma, } \\
\text { Nasal glial } \\
\text { heterotopia, } \\
\text { Benign Triton tumor, } \\
\text { Hybrid nerve sheath } \\
\text { tumors }\end{array}$ & $\begin{array}{l}\text { Nodular fasciitis } \\
\text { Proliferative fasciitis } \\
\text { Proliferative myositis } \\
\text { Ischemic fasciitis } \\
\text { Fibrous hamartoma of } \\
\text { infancy } \\
\text { Gardner fibroma } \\
\text { Desmoids-type } \\
\text { fibromatosis } \\
\text { Calcifying fibrous tumor } \\
\text { Ossifying fibromyxoid } \\
\text { tumor } \\
\text { Myositis ossificans } \\
\text { Fibro-osseous } \\
\text { pseudotumor of digits } \\
\text { Juvenile hyaline } \\
\text { fibromatosis } \\
\text { Inclusion body } \\
\text { fibromatosis } \\
\text { Fibroma of the tendon } \\
\text { sheath } \\
\text { Desmoplastic } \\
\text { fibroblastoma } \\
\text { Mammary-type } \\
\text { myofibroblastoma } \\
\text { Calcifying aponeurotic } \\
\text { fibroma } \\
\text { Angiomyofibroblastoma } \\
\text { Cellular angiofibroma } \\
\text { Nuchal-type fibroma } \\
\text { Lipofibromatosis } \\
\text { Giant cell fibroblastoma }\end{array}$ & $\begin{array}{l}\text { Tenosynovial giant } \\
\text { cell tumor, } \\
\text { Giant cell tumor of } \\
\text { soft tissue, } \\
\text { Intramuscular } \\
\text { myxoma, } \\
\text { Phosphaturic } \\
\text { mesenchymal } \\
\text { tumor, }\end{array}$ \\
\hline ST-RADS IV & $\begin{array}{l}\text { Atypical } \\
\text { lipomatous } \\
\text { tumor, Well- } \\
\text { differentiated } \\
\text { liposarcoma }\end{array}$ & $\begin{array}{l}\text { Kaposiform } \\
\text { haemangioendothelioma, } \\
\text { Retiform } \\
\text { haemangioendothelioma, } \\
\text { Papillary intralymphatic } \\
\text { angioendothelioma, } \\
\text { Composite } \\
\text { haemangioendothelioma, } \\
\text { Pseudomyogenic } \\
\text { (epithelioid sarcoma-like) } \\
\text { haemangioendothelioma, } \\
\text { Kaposi sarcoma, }\end{array}$ & $\begin{array}{l}\text { Malignant } \\
\text { perineurioma }\end{array}$ & $\begin{array}{l}\text { Solitary fibrous tumor } \\
\text { Inflammatory } \\
\text { myofibroblastic tumor } \\
\text { Low-grade } \\
\text { myofibroblastic } \\
\text { sarcoma } \\
\text { Myxoinflammatory } \\
\text { fibroblastic sarcoma / } \\
\text { Infantile fibrosarcoma }\end{array}$ & $\begin{array}{l}\text { Leiomyosarcoma, } \\
\text { Synovial sarcoma, } \\
\text { Undifferentiated } \\
\text { spindle cell } \\
\text { sarcoma, } \\
\text { Undifferentiated } \\
\text { pleomorphic } \\
\text { sarcoma, } \\
\text { Undifferentiated } \\
\text { round cell sarcoma, }\end{array}$ \\
\hline ST-RADS V & $\begin{array}{l}\text { Dedifferentiated } \\
\text { liposarcoma } \\
\text { Myxoid } \\
\text { liposarcoma } \\
\text { Pleomorphic } \\
\text { liposarcoma } \\
\text { Liposarcoma, }\end{array}$ & $\begin{array}{l}\text { Epithelioid } \\
\text { haemangioendothelioma, } \\
\text { Angiosarcoma of soft } \\
\text { tissue }\end{array}$ & $\begin{array}{l}\text { Malignant peripheral } \\
\text { nerve sheath tumor, } \\
\text { Epithelioid } \\
\text { malignant nerve } \\
\text { sheath tumor, } \\
\text { Malignant Triton } \\
\text { tumor, }\end{array}$ & $\begin{array}{l}\text { Dermatofibrosarcoma } \\
\text { protuberans } \\
\text { Adult fibrosarcoma } \\
\text { Myxofibrosarcoma } \\
\text { Low-grade fibromyxoid } \\
\text { sarcoma } \\
\text { Sclerosing epithelioid }\end{array}$ & $\begin{array}{l}\text { Undifferentiated } \\
\text { epithelioid sarcoma, } \\
\text { Undifferentiated } \\
\text { sarcoma NOS } \\
\text { Epithelioid sarcoma, }\end{array}$ \\
\hline
\end{tabular}


not otherwise

specified.
Malignant granular cell tumor,

Ectomesenchymoma fibrosarcoma
Alveolar soft-part sarcoma,

Clear cell sarcoma of soft tissue,

Extraskeletal myxoid chondrosarcoma,

Extraskeletal Ewing sarcoma,

Desmoplastic small round cell tumor,

Embryonal

rhabdomyosarcoma, Alveolar

rhabdomyosarcoma, Pleomorphic rhabdomyosarcoma, Spindle cell / Sclerosing rhabdomyosarcoma, Extraskeletal osteosarcoma
ST-RADS VI Known biopsyproven

malignancy or recurrent

malignancy in the tumor bed
Known biopsy-proven malignancy or recurrent malignancy in the tumor bed
Known biopsy-proven malignancy or recurrent malignancy in the tumor bed
Known biopsy-proven malignancy or recurrent malignancy in the tumor bed
Known biopsyproven malignancy or recurrent malignancy in the tumor bed

Table 3: Soft tissue tumors tested in the study for validation (200 total assessed- 100 adipocytic, 50 T2-hyperintense, and 50 T2-hypointensenumbers of lesions tested are highlighted in parentheses) 


\begin{tabular}{|c|c|c|c|c|}
\hline Classification & Category & Adipocytic tumors (100) & T2-hyperintense Lesions (50) & T2-hypointense Lesions (50) \\
\hline ST-RADS 0 & $\begin{array}{l}\text { Incomplete } \\
\text { imaging }\end{array}$ & - & - & - \\
\hline ST-RADS I & $\begin{array}{l}\text { No lesion } \\
\text { identified }\end{array}$ & - & - & - \\
\hline ST-RADS II & $\begin{array}{l}\text { Definitely } \\
\text { benign }\end{array}$ & $\begin{array}{l}\text { Lipomatosis (1), Lipoma (17), } \\
\text { Fibrolipoma of nerve (2), } \\
\text { Dermatolipoma (1), Fat } \\
\text { necrosis (1), Hematoma (3), } \\
\text { Hemangioma (3), Lymphedema } \\
\text { (1), lipoma arborescence (1), } \\
\text { Elastofibroma (1) }\end{array}$ & $\begin{array}{l}\text { Geyser (2), Parameniscal cyst (1), } \\
\text { Hemangioma ( } 3 \text {,, Paralabral cyst } \\
\text { (2), Venous malformation (1), } \\
\text { Degloving lesion (1), Ganglion } \\
\text { cyst (1) }\end{array}$ & Plantar fibroma (1), Gout (3) \\
\hline ST-RADS III & $\begin{array}{l}\text { Probably } \\
\text { benign }\end{array}$ & $\begin{array}{l}\text { Lipoblastoma (1), Angiolipoma } \\
\text { (7), } \\
\text { Myolipoma of soft tissue (1), } \\
\text { Chondroid lipoma (1), } \\
\text { Spindle cell / pleomorphic } \\
\text { lipoma (6) } \\
\text { Hibernoma (3), myositis } \\
\text { ossificans (1) }\end{array}$ & $\begin{array}{l}\text { Myxoma (7), Bursitis } \\
\text { (Rheumatoid, subtendinous, } \\
\text { adventitial) (4), Hematoma (3), } \\
\text { Intraneural ganglion (2), Seroma } \\
\text { (1), Benign PNST (3), } \\
\text { Cysticercosis (1), Mycobacterial } \\
\text { TS (1), Abscess (1), Desmoid (1) }\end{array}$ & $\begin{array}{l}\text { Desmoid (4), TSGCT (4), } \\
\text { Desmoplastic fibroblastoma (7), } \\
\text { Ossifying fibromyxoid tumor (2), } \\
\text { Pilomatricoma (2), Fibroma of } \\
\text { tendon sheath (1), Granular cell } \\
\text { tumor (1) }\end{array}$ \\
\hline ST-RADS IV & $\begin{array}{l}\text { Suspicious } \\
\text { for } \\
\text { malignancy } \\
\text { or } \\
\text { indeterminate }\end{array}$ & $\begin{array}{l}\text { Atypical lipomatous tumor } \\
\text { andWell-differentiated } \\
\text { liposarcoma (13) }\end{array}$ & Cellular fibromatosis (1) & - \\
\hline \multirow[t]{2}{*}{ ST-RADS V } & $\begin{array}{l}\text { Highly } \\
\text { suggestive of } \\
\text { malignancy }\end{array}$ & $\begin{array}{l}\text { Dedifferentiated liposarcoma } \\
(11) \text {, } \\
\text { Myxoid liposarcoma (21), } \\
\text { Pleomorphic liposarcoma (2), } \\
\text { Liposarcoma, not otherwise } \\
\text { specified (2) }\end{array}$ & $\begin{array}{l}\text { Sarcoma (5), Synovial sarcoma } \\
\text { (3), Myxoid liposarcoma (6) }\end{array}$ & $\begin{array}{l}\text { Undifferentiated pleomorphic } \\
\text { sarcoma (5), Extraskeletal } \\
\text { osteosarcoma (6), Synovial } \\
\text { sarcoma (3), Fibrosarcoma- } \\
\text { epithelioid (5) myxofibrosarcoma } \\
\text { (3), Fibromyxoid sarcoma (1), } \\
\text { Sarcoma NOS (1), }\end{array}$ \\
\hline & & & & Fibrosarcoma (1), \\
\hline ST-RADS VI & $\begin{array}{l}\text { Known } \\
\text { biopsy- } \\
\text { proven } \\
\text { malignancy } \\
\text { or recurrent } \\
\text { malignancy } \\
\text { in the tumor } \\
\text { bed }\end{array}$ & None & None & - \\
\hline
\end{tabular}

Table 4: Readers' experiences.

\begin{tabular}{lll} 
Readers & Institution & Experience \\
\hline Rad 1 & Institute 1 & $>30$ years \\
\hline Rad 2 & Institute 1 & $>$ 30 years \\
\hline Rad 3 & Institute 2 & 12 years \\
\hline $\operatorname{Rad} 4$ & Institute 2 & 11 years \\
\hline Rad 5 & Institute 1 & 8 years \\
\hline $\operatorname{Rad} 6$ & Institute 2 & 6 years \\
\hline $\operatorname{Rad} 7$ & Institute 2 & 6 years \\
\hline $\operatorname{Rad} 8$ & Institute 3 & 2 years
\end{tabular}

Table 5: Intraclass correlation with a mixed-effects model used for inter-reader agreement. 


\begin{tabular}{|lll|}
\hline Dataset & ICC & Interpretation \\
\hline T2-hyperintense masses & $0.69(0.59,0.70)$ & Good \\
\hline T2-hypointense masses & $0.51(0.37,0.65)$ & Fair \\
\hline Adipocytic tumors & $0.72(0.64,0.79)$ & Good \\
\hline
\end{tabular}

Table 6: Sensitivity and specificity of ST-RADS for soft tissue masses.

\begin{tabular}{|lll|}
\hline & Sensitivity & Specificity \\
\hline T2-hyperintense masses & $93 \%$ & $71 \%$ \\
\hline T2-hypointense masses & $64 \%$ & $84 \%$ \\
\hline Adipocytic tumors & $96 \%$ & $63 \%$ \\
\hline
\end{tabular}

Table 7: Statistics of reader-reliability and diagnostic performance based on readers experiences of less than 10 years (4) and more than 10 years (4).

\begin{tabular}{lll} 
ICC & $<10$ years & $>10$ years \\
\hline Adipocytic tumors & $0.75(0.65,0.83)$ & $0.71(0.60,0.80)$ \\
\hline T2-hyperintense masses & $0.69(0.56,0.79)$ & $0.21(0.06,0.40)$ \\
\hline T2-hypointense tumors & $0.48(0.31,0.64)$ & $0.50(0.26,0.69)$
\end{tabular}

\begin{tabular}{lll} 
AUC & $<10$ years & $>10$ years \\
\hline Adipocytic tumors & $0.84(0.76,0.91)$ & $0.83(0.76,0.91)$ \\
\hline T2-hyperintense masses & $0.94(0.86,0.99)$ & $0.85(0.76,0.95)$ \\
\hline T2-hypointense tumors & $0.75(0.63,0.88)$ & $0.86(0.76,0.96)$
\end{tabular}

\begin{tabular}{lll} 
Sens/spec & $<10$ years & $>10$ years \\
\hline Adipocytic tumors & $98 \% / 59 \%$ & $92 \% / 57 \%$ \\
\hline T2-hyperintense masses & $100 \% / 80 \%$ & $87 \% / 71 \%$ \\
\hline T2-hypointense tumors & $68 \% / 72 \%$ & $80 \% / 80 \%$
\end{tabular}

\section{Figures}



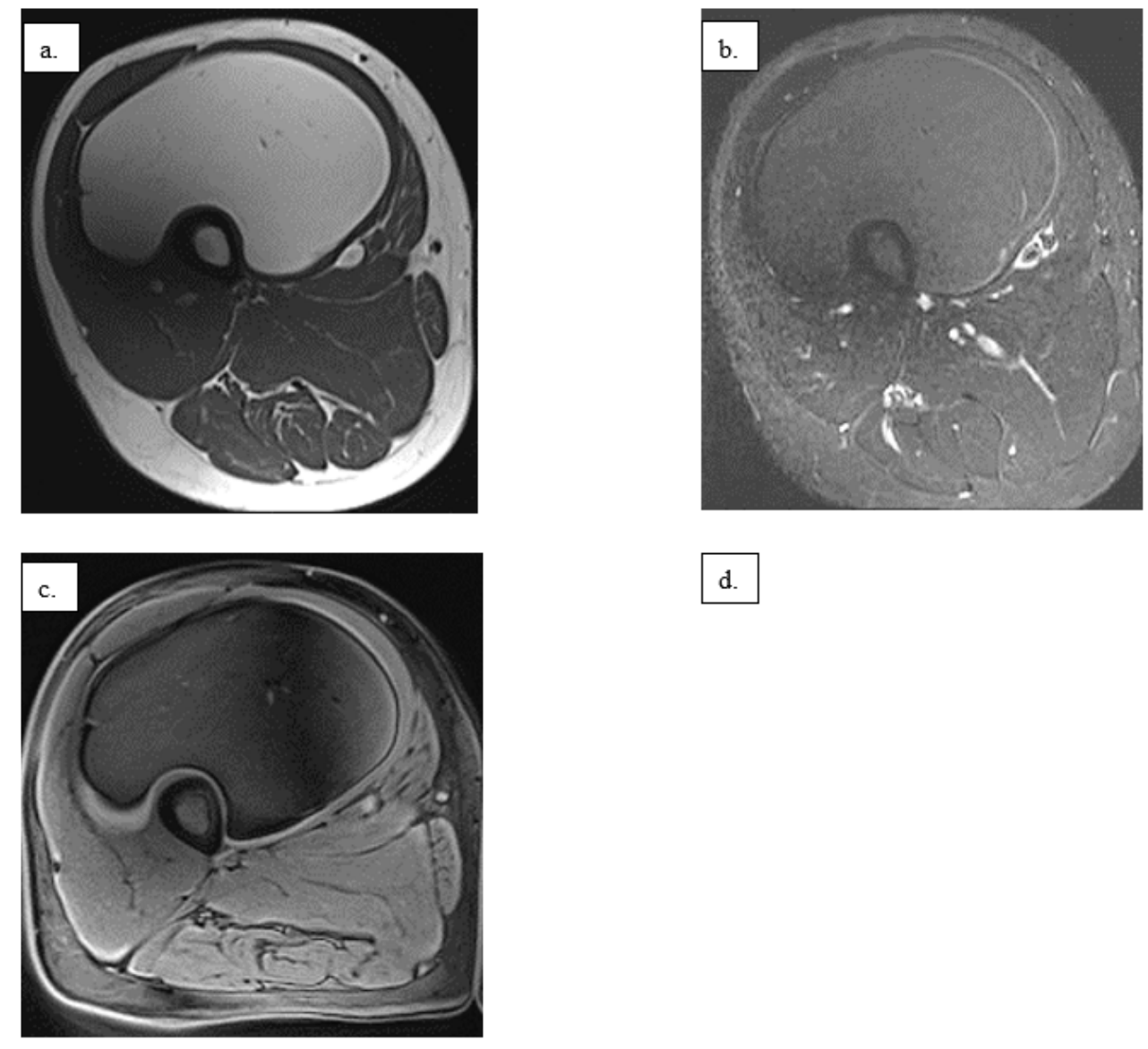

d.

Figure 1

ST-RADS II - Axial T1W (a), T2W fat-suppressed (b), pre-contrast fat-suppressed (c), and post-contrast T1W (d - not available with this version) images show a well-defined T1-hyperintense homogenous anterior thigh mass completely suppressed on fat-saturated images with no enhancement, with a pathological diagnosis of simple lipoma. All readers classified this lesion as ST-RADS II. 


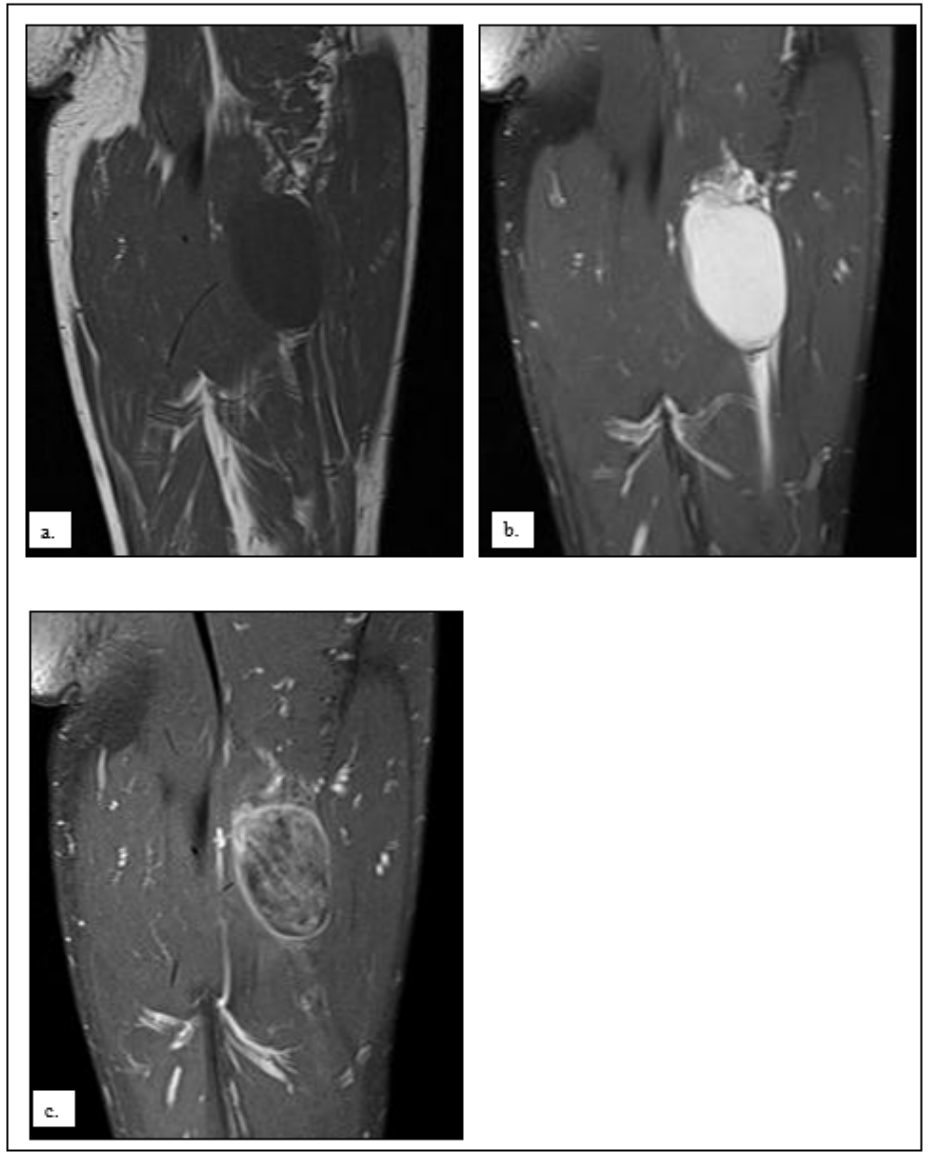

Figure 2

ST-RADS III - Coronal T1W (a), fat-suppressed T2W (b), and post-contrast T1W (c) images show a well-defined T1-hypointense, T2-hyperintense thigh mass with heterogeneous enhancement in intramuscular location, with pathological diagnosis of myxoma. Different readers classified this lesion as ST-RADS II, III, and IV. 


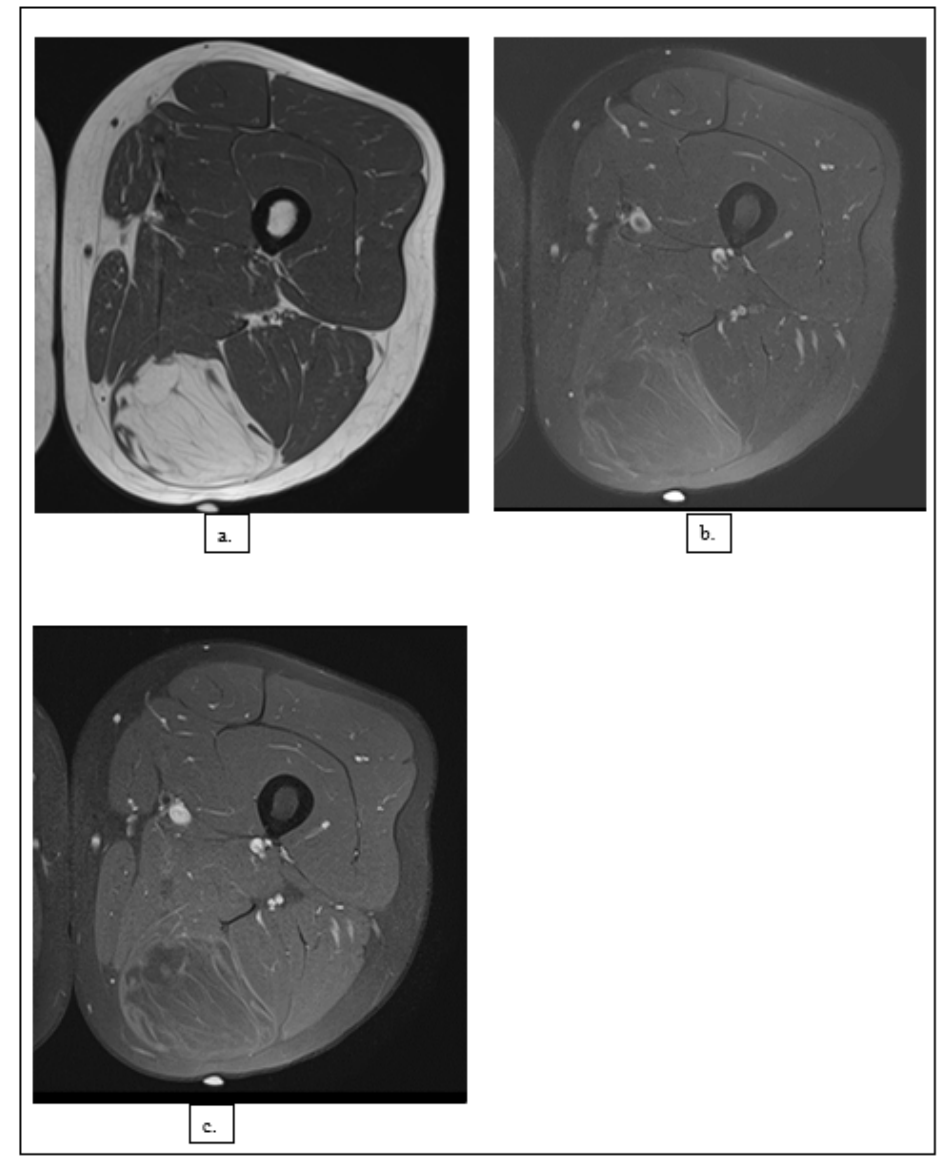

Figure 3

ST-RADS IV - Axial T1W (a), fat-suppressed T2W (b), and post-contrast T1W (c) images show a well-defined mildly heterogeneously T1hyperintense mass with multiple septations, with incomplete signal suppression on fat saturation and mild enhancement of the internal septations, with pathological diagnosis of atypical lipomatous tumor. The readers classified this lesion as ST-RADS IV and V. 


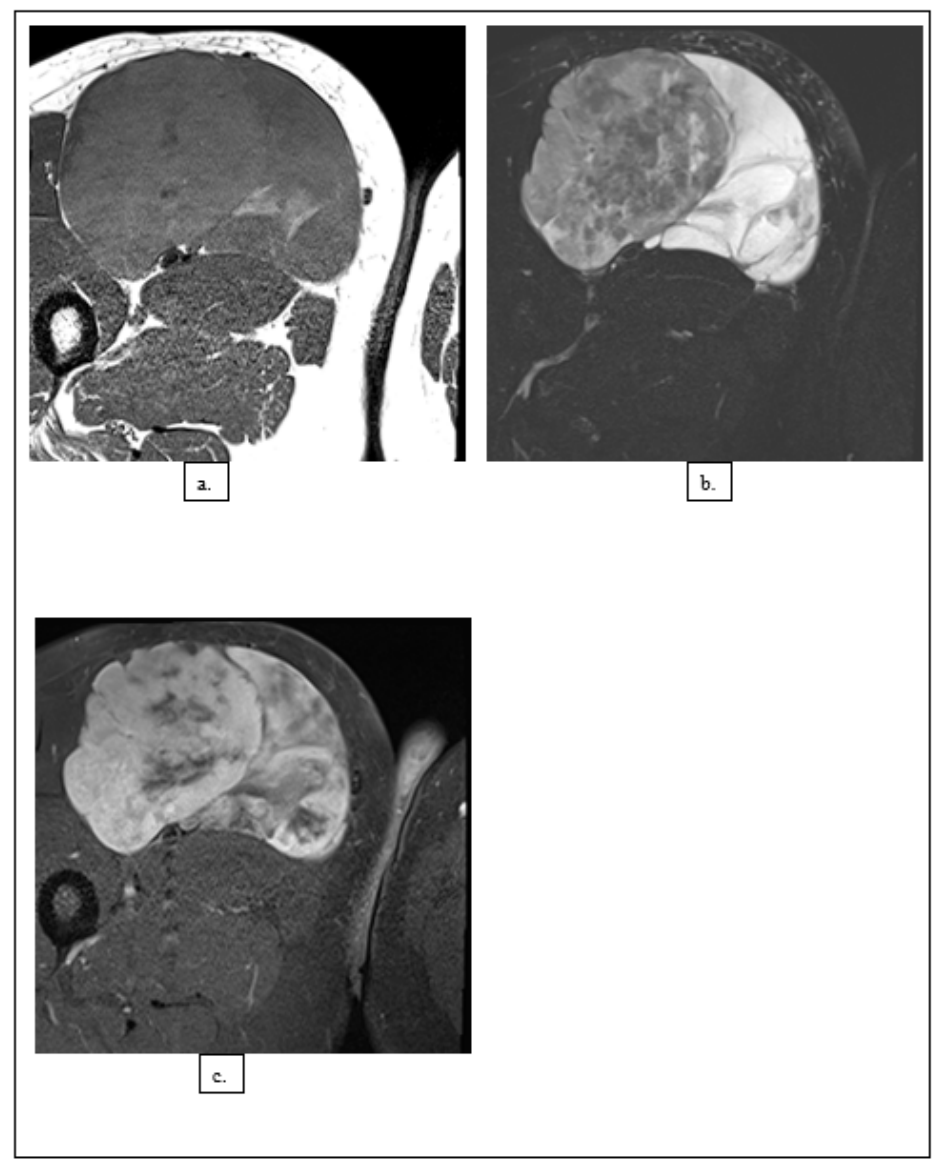

\section{Figure 4}

ST-RADS V - Axial T1W (a), fat-suppressed T2W (b), and post-contrast T1W (c) images show a heterogeneous anterior thigh mass with small T1-hyperintense fat component, predominantly T2-hyperintense heterogeneous signal with heterogeneous enhancement, with pathological diagnosis of myxoid liposarcoma. All readers classified this lesion as ST-RADS V. 


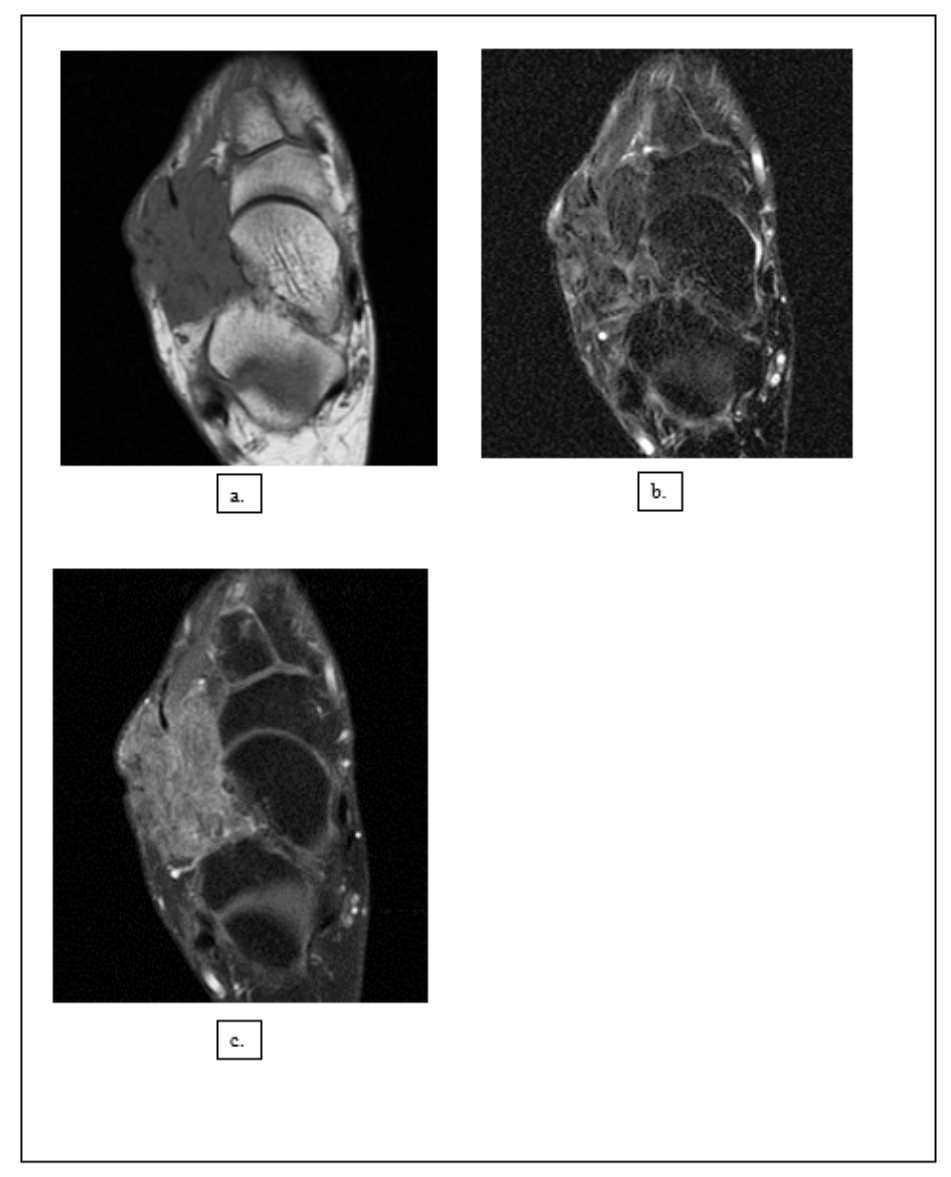

\section{Figure 5}

ST-RADS V - Axial T1W (a), fat-suppressed T2W (b), and post-contrast T1W (c) images show a medial foot mass, predominantly T2hypointense heterogeneous signal with heterogeneous enhancement, with pathological diagnosis of desmoplastic fibroblastoma. All readers classified this lesion as ST-RADS III and V. 


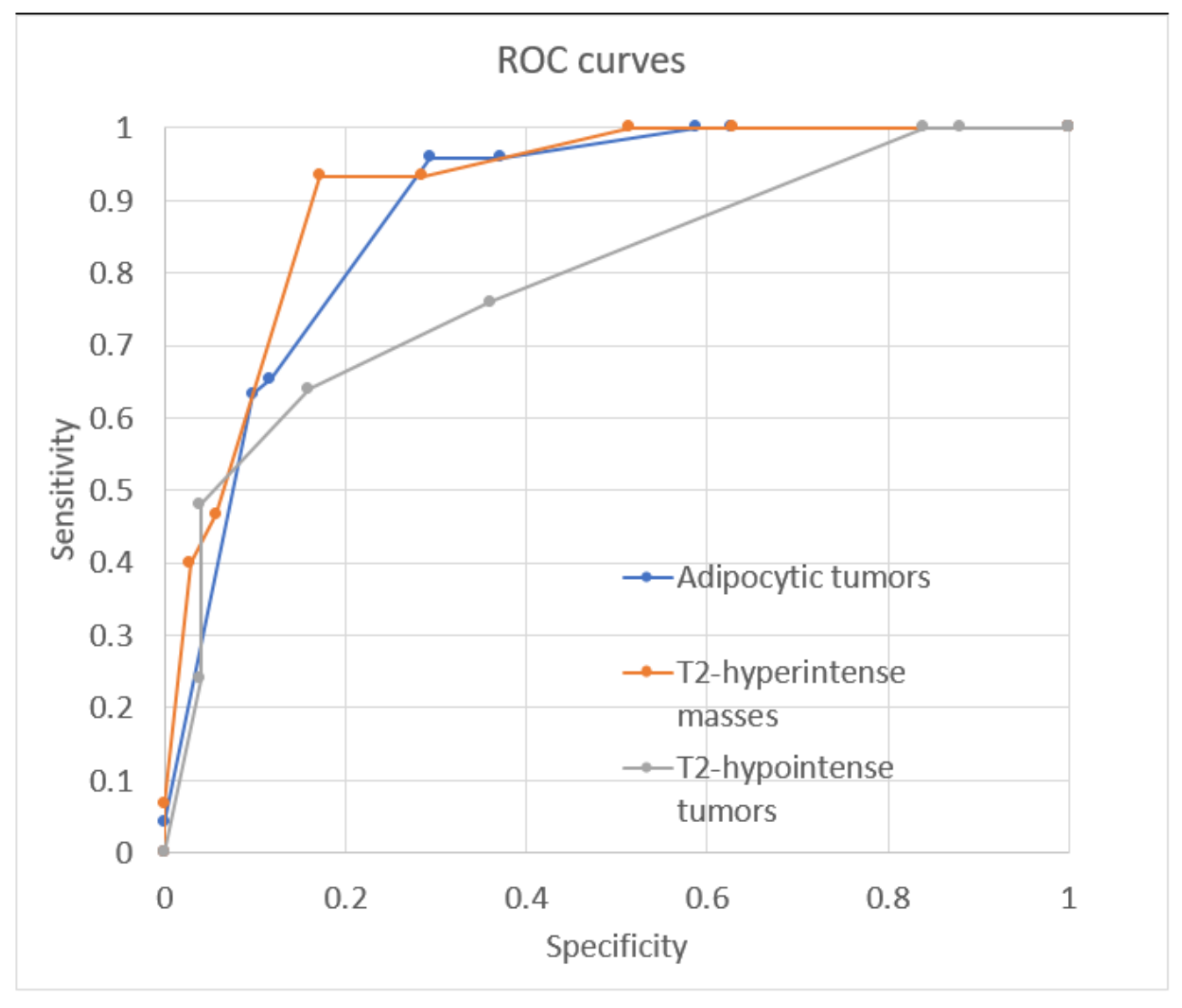

Figure 6

ROC curves for all masses (AUC 0.79-0.89). 